\title{
Antarctic sessile marine benthos: colonisation and growth on artificial substrata over three years
}

\author{
David A. Bowden*, Andrew Clarke, Lloyd S. Peck, David K. A. Barnes \\ Natural Environment Research Council, British Antarctic Survey, High Cross, Madingley Road, Cambridge CB3 0ET, UK
}

\begin{abstract}
The development of sessile invertebrate assemblages on hard substrata has been studied extensively in temperate and tropical latitudes. Such studies provide insights into a range of ecological processes, and the global similarity of taxa recruiting to these assemblages affords the potential for regional-scale comparisons. However, few data exist for high latitude assemblages. This paper presents the first regularly resurveyed study of benthic colonisation from within the Antarctic Circle. Acrylic panels were deployed horizontally on the seabed at 8 and $20 \mathrm{~m}$ depths at each of 3 locations in Ryder Bay, Adelaide Island, SW Antarctic Peninsula $\left(67^{\circ} 35^{\prime} \mathrm{S}, 68^{\circ} 10^{\prime} \mathrm{W}\right)$. Assemblages colonising upward- and downward-facing panel surfaces were photographed in situ from February 2001 to March 2004. Assemblages were dominated by bryozoans and spirorbid polychaetes. Total coverage after 3 yr ranged from 6 to $100 \%$ on downward-facing surfaces but was $<10 \%$ on all upward-facing surfaces. Overall colonisation rates were up to 3 times slower than comparable temperate latitude assemblages but showed unexpected similarities with a tropical assemblage. Growth in most taxa was highly seasonal and maximum growth rates of encrusting bryozoans were 5 to 10 times slower than literature values for temperate species, suggesting rate limitation by cold rather than food availability. Assemblage development was controlled predominantly by post-settlement disturbances, and there was considerable variability between locations associated with differences in disturbance history. Ice impact was significant only at $8 \mathrm{~m}$ but biotic disturbances exerted a stronger and more consistent influence on assemblage development at all sites. It is suggested that the combination of slow growth rates and strong environmental seasonality results in succession being more predictable than in comparable temperate or tropical assemblages.
\end{abstract}

KEY WORDS: Marine benthos · Settlement panels $\cdot$ Polar habitat · Assemblage succession · Growth · Disturbance written consent of the publisher

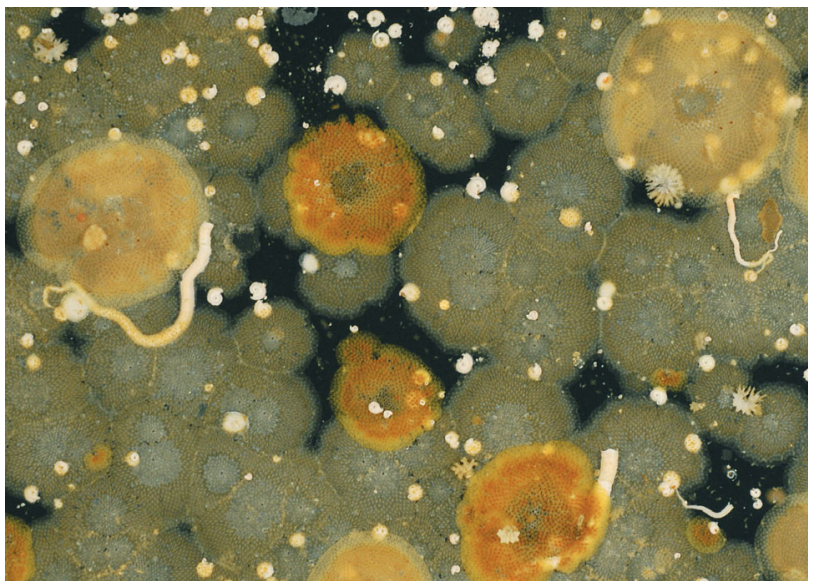

Bowden and co-workers present the first successful benthic colonisation study from within the Antarctic Circle. They describe a system governed by extremely slow and highly seasonal growth, and a range of post-settlement disturbances in which succession is more predictable than in comparable temperate or tropical assemblages.

Photo: David A. Bowden

\section{INTRODUCTION}

Sublittoral sessile epifaunal assemblages are often characterised by similar groups of organisms. Bryozoans, calcareous polychaetes, sponges, ascidians, and hydrozoans are common components of hardsubstratum sessile assemblages at all latitudes, and it is not uncommon for genera to be globally distributed (e.g. Spirorbis, Celleporella, Ascidia). Such assemblages, therefore, potentially allow comparisons of the effects of environmental variation on basic biological and ecological processes to be made between regions. The relative ease with which such assemblages can be studied and manipulated, and their suitability for investigation by means of artificial colonisation sub- 
strata, further enhance the potential for regional or latitudinal comparisons (e.g. Sutherland 1974, Schoener et al. 1978, Holmes et al. 1997, Witman et al. 2004). Most studies to date, however, have been conducted in temperate and tropical latitudes, and comparable data from higher latitudes are sparse.

The Antarctic benthos has been studied from the earliest expeditions and there has been much interest in the rates of biological and ecological processes in relation to other latitudes (See reviews by Clarke 1991, Arntz et al. 1994). Antarctic seas are of particular relevance to such studies because environmental seasonality is at its most extreme, and seawater temperatures are exceptionally low and stable throughout the year (Clarke 1988, Clarke \& Leakey 1996). However, with notable exceptions (Dayton et al. 1974, Dayton 1989, Stanwell-Smith \& Barnes 1997), the majority of studies to date have involved description of instantaneous pattern, from which the rates and causal mechanisms of underlying processes are largely inferred (e.g. Barnes \& Arnold 2001, Gutt \& Starmans 2001, Teixido et al. 2002). This is primarily a consequence of sampling difficulties associated with the slow rates of biological processes in the region and loss of equipment through ice impacts during prolonged deployment.

Existing studies of benthic assemblages in Antarctic nearshore environments suggest 3 distinctive characteristics. First, growth in most taxa is slow by comparison with similar taxa at lower latitudes (Pearse et al. 1991, Stanwell-Smith \& Barnes 1997, Clarke et al. 2004). This may be due to physiological limitations associated with low temperature, food limitation due to temporally-limited primary production, or a combination of these factors; however, to date the evidence is not conclusive (Clarke 1991, Hoegh-Guldberg \& Pearse 1995, Fraser et al. 2002a, Clarke et al. 2004). Second, growth in many taxa is restricted to the summer period of primary production. Although shell growth in brachiopods and at least 1 infaunal bivalve species takes place during winter (Peck et al. 1997, Peck et al. 2000), and some bryozoans feed actively throughout the year (Barnes 1995, Barnes \& Clarke 1995), growth in vagile benthic taxa is highly seasonal (Brockington et al. 2001, Fraser et al. 2002b) and for the majority of sessile taxa seasonality of growth has not been measured. Third, the gradient of decreasing physical disturbance by ice with increasing depth is the principal factor determining sessile assemblage structure in nearshore waters (Dayton 1990, Arntz et al. 1994, Barnes 1999, Gutt 2001). Again, although the characteristic zonation of nearshore benthic assemblages in the region is probably caused by this gradient, to date only 1 study has directly linked differences in the frequency of ice disturbance to differences in assemblage structure (Brown et al. 2004).
Only 1 regularly resurveyed colonisation study has been reported from the Antarctic to date (StanwellSmith \& Barnes 1997), but this was from an arguably unrepresentative location in the maritime Antarctic (Signy Island, $60^{\circ} 43^{\prime} \mathrm{S}, 45^{\circ} 36^{\prime} \mathrm{W}$ ). The only reports available from continental locations provide very limited information but suggest that growth may not be slow in all taxa (Rauschert 1991) and that recruitment may be highly episodic in some locations (Dayton 1989). In the context of very limited knowledge of colonisation processes in the Antarctic, the principal aim of the present study was to generate accurate data on the growth and survivorship of sessile assemblages following initial recruitment. To this end, in situ photographic techniques were used to monitor colonisation of artificial hard substrata. In expectation of slow rates of colonisation and growth (Barnes 1996, StanwellSmith \& Barnes 1997), the study was designed to span 3 annual cycles and to incorporate sufficient replication of locations, and experimental units within locations, to characterise the range of local variability. Beyond these basic requirements, the 3 assumptions listed above were taken as working hypotheses: (1) growth is slow by comparison with similar assemblages at lower latitudes; (2) growth is highly seasonal and is governed by the summer pulse of primary production; (3) differences in the frequency of disturbance by ice are responsible for the observed zonation of sessile assemblages. In a parallel study at the same experimental sites, Bowden (2005a) recorded the diversity and abundance of larval recruitment at monthly intervals through 2002-2003. Thus, the survivorship and growth of adult organisms reported in the present study occurred in the context of the levels of larval recruitment detailed in Bowden (2005a).

\section{MATERIALS AND METHODS}

Study sites and materials. The study was conducted at 3 locations: Hangar Cove, South Cove, and Anchorage Island (Fig. 1) close to the British Antarctic Survey research station at Rothera Point, Adelaide Island, west Antarctic Peninsula (67 $\left.34.5^{\prime} \mathrm{S}, 68^{\circ} 07.0^{\prime} \mathrm{W}\right)$. The physical and biological characteristics of the study sites are described in Bowden (2005b), and the settlement plate units used are described in detail in Bowden (2005a). Briefly, arrays of 6 settlement plate units were deployed at each of 2 depths ( 8 and $20 \mathrm{~m}$ ) at each of the 3 locations. Plates were constructed from roughened opaque black acrylic sheet and were $250 \times 150 \times 5 \mathrm{~mm}$ overall with registration points for a central $150 \times$ $100 \mathrm{~mm}$ analysis area marked on each face. Plates were deployed horizontally fastened rigidly to individual $25 \mathrm{~kg}$ concrete sinkers such that there was 


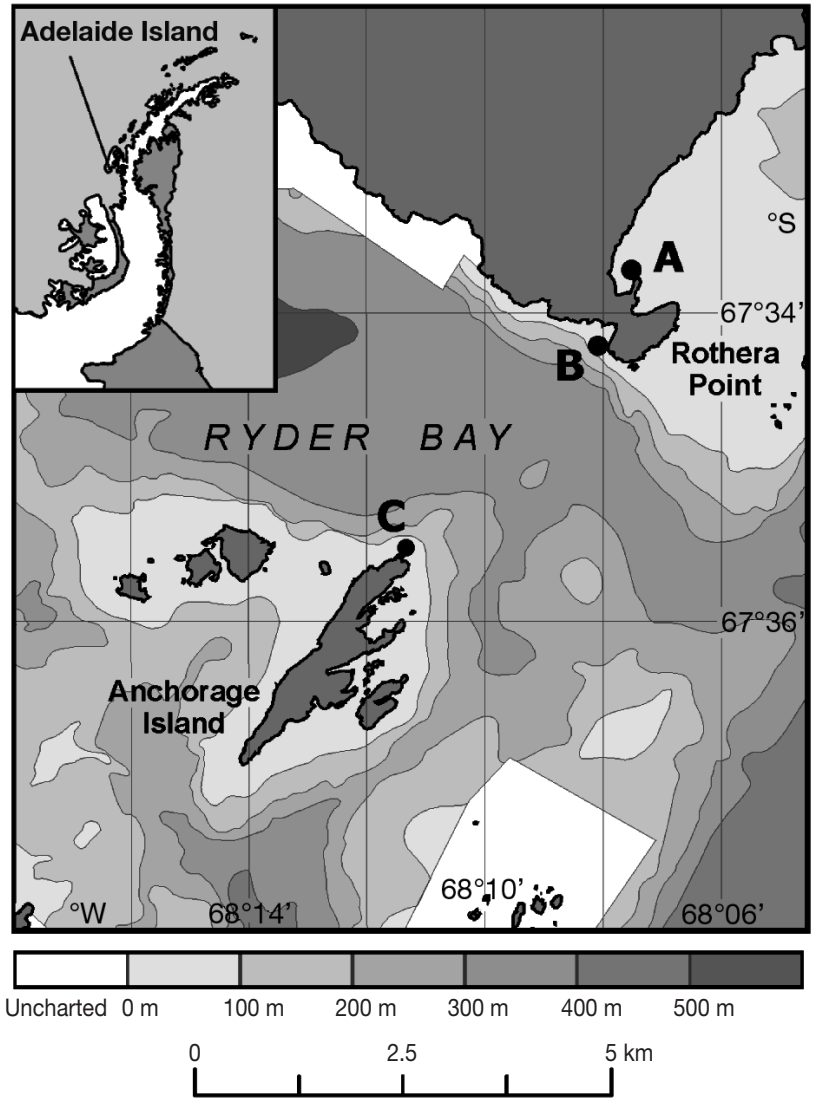

Fig. 1. The Antarctic Peninsula and Adelaide Island (inset), with details of Ryder Bay showing the 3 colonisation study locations -A: Hangar Cove; B: South Cove; and C: Anchorage Island

a $10 \mathrm{~mm}$ gap between the lower surface of the plate and the sinker. Thus, the lower surfaces of plates were less accessible to larger grazing and predatory macrofauna than were the exposed upper surfaces. Each plate was located on 4 nylon studs protruding from the sinker and was secured by means of elastic cord such that it could be easily removed and inverted in situ for photography of undersurfaces

Plate deployment and sampling. Settlement plates were deployed at all sites in February 2001, and assemblages recruiting to both upward and downward facing surfaces of all plates were monitored at intervals through a 3 yr period of continuous immersion. Plates were photographed in situ by divers using SCUBA. Photographs were taken on ISO 50 colour reversal film using a Nikonos V $35 \mathrm{~mm}$ camera with $28 \mathrm{~mm}$ lens and Nikonos close-up attachment. Lighting was from a Nikon SB105 Speedlight with diffuser.

Diving facilities together with all records from the first 6 mo of the study were lost in a laboratory fire; consequently the first data point was in April 2002, at the end of first year of immersion. From this point, plates were monitored at the beginning of each calen- dar month until March 2003. At each visit, 1 photograph was taken of each plate surface (upper and lower). In March 2003, a set of 4 overlapping 2:1 macro photographs was taken of the central analysis area of each plate surface to confirm identifications of colonists. In February 2004, all plates were recovered from the seabed and examined under low-power microscopy in the aquarium. At the same time, highresolution digital photographs were taken of whole assemblages to map colonised areas and of individual colonists to confirm identifications. These detailed examinations (March 2003 and February 2004) also allowed individual colonies to be traced back beyond the point at which their identities could first be resolved from the earlier in situ images: by matching the spatial coordinates of an individual, or the ancestrula of a particular colony, in these images with corresponding targets in the preceding in situ images, its history could be traced to its first appearance on the plates.

Image analysis. Transparencies of plate surfaces were scanned at a resolution of $600 \mathrm{dpi}$. Digital images were then cropped to the central $150 \mathrm{~cm}^{2}$ analysis area registration marks, corrected for minor parallax distortions, and resized to allow global measurement calibration. Image analysis was based on the 'interactive colour segmentation' method described by Bernhardt \& Griffing (2001) using Adobe Photoshop 7 (Adobe Systems) and image analysis routines in Fovea Pro 3 (Reindeer Graphics). Colonies and individuals were segmented on the basis of their projected area visible in the image. Thus, where overgrowth occurred and where there was significant 3-dimensional structure (which was rare) only the area covered by the uppermost colony or individual was recorded. The fully segmented images enabled areal coverage of each taxon together with a comprehensive range of positional and form-factor parameters for each colonist to be measured automatically using Fovea Pro 3.

Growth measurement. Whole-assemblage growth was recorded as change in total percentage area of the substratum covered by sessile organisms at successive sampling points. Initial comparisons were made between total areal coverage at the 3 successive year-end points of the study (April 2002, March 2003, February 2004). These allowed annual rates of increase to be compared between locations, depths and years. These rates were then considered in the light of seasonal changes in total colonised area measured at monthly increments through the second year of the study (April 2002-March 2003).

Area measurements of a single taxon over the entire analysis area combine all recruits, regardless of their disturbance history, and thus integrate growth, recruitment, and mortality. However, for some taxa, by mea- 
suring only individuals or colonies which were unaffected by predation, spatial competition or other disturbance over the observation period, it was possible to measure growth independently. For these measurements of taxon-specific growth, areal coverage of individual specimens was measured at successive monthly sampling points through the second year of the study.

Growth of encrusting cheilostome bryozoans is usually presented as the increase in area or number of zooids; however, increase in maximum radius $\left(\mathrm{O}^{\prime} \mathrm{Dea}\right.$ \& Okamura 1999) and a specific growth rate index based on an exponential growth model (Hermansen et al. 2001) have also been used. Here, growth data derived by all 3 metrics were calculated to allow comparisons across a wider range of studies in the literature. Radial growth rate (r) was calculated for each monthly period as:

$$
\mathrm{r}=\frac{\left(\frac{D_{\text {eq1 }}-D_{\text {eq0 }}}{2}\right)}{t}
$$

where $D_{\text {eq1 }}$ is the diameter of a circle enclosing the same area as the measured colony (equivalent diameter) at the end of the growth period, $D_{\text {eq0 }}$ is the equivalent diameter at the start of the growth period and $t$ is the growth period in days. Using this metric instead of direct measurement of radius facilitated the automation of measurement and avoided errors associated with reliably determining the colony centre in successive images. The specific growth rate for each monthly growth increment was calculated from Eq. (3) in Hermansen et al. (2001):

$$
\mu=\frac{\ln \left(\frac{N}{N_{0}}\right)}{t}
$$

where $\mu$ is the specific growth rate, $N$ is colony area at the end of the growth period, $N_{0}$ is area at the start of the growth period and $t$ is the growth period in days.

Assemblage comparisons. The presence or absence of sessile taxa on plates at the end of 3 yr was compared with full taxon lists from (1) a survey of surrounding natural substrata at the study sites (data from Bowden 2005b), and (2) a study of larval recruitment to artificial substrata at the study sites at monthly intervals during the year April 2002 to March 2003 (data from Bowden 2005a).

Multivariate comparisons based on percentage cover data for all taxa on the experimental substrata after 3 yr immersion were conducted using the PRIMER v 5.2.0 statistical package (PRIMER-E, Plymouth; Clarke \& Warwick 2001). The similarities percentages routine (SIMPER) was used to identify the taxa contributing most to similarities between assemblages on replicate plates at each site (i.e. depth $\times$ location). The ANOSIM (analysis of similarities) $R$ statistic was used to quantify variations in overall pairwise similarity between assemblages at different sites. ANOSIM is a permutationbased significance test for multivariate data, which compares rank similarities between pairs of samples from different groups in a matrix of Bray-Curtis similarities. However, the $R$ statistic ranges between +1 and -1 and can be used independently as a direct comparative measure of the degree of separation between groups of samples (Clarke \& Warwick 2001). Values closer to zero indicate greater similarity between sample groups, and a value of 1 indicates complete dissimilarity.

\section{RESULTS}

\section{Ice damage}

During the 3 yr immersion period, 9 units were damaged by ice impact; all of these were at $8 \mathrm{~m}$ sites. In addition, 1 unit at the $20 \mathrm{~m}$ site in South Cove was damaged by rock-fall, presumably caused by ice impact above the site. In each case, a new plate was installed and monitoring continued as before. These plates were considered to represent patches of natural substratum from which all sessile taxa have been removed by ice scour and on which assemblage development begins again from first colonisation. At each of the $8 \mathrm{~m}$ sites, ice damage occurred only once during the $3 \mathrm{yr}$ of the study.

\section{Taxonomic diversity}

A total of 31 sessile faunal taxa from 6 phyla, together with 1 coralline alga, were recorded within the central analysis areas of the plates (Table 1). Cheilostome bryozoans were readily identified from photographs, usually to species level. Other taxa could generally be differentiated consistently on the basis of appearance but many could not be identified to species without removal from the plates and consequent disturbance of the assemblage. Thus, 3 types of sponge (distinguished by colour), 4 types (genera) of cyclostome bryozoan, 2 types (1 genus, 1 species) of solitary ascidian, and 2 types (1 genus, 1 indeterminate) of hydrozoan were recorded, while spirorbid and serpulid polychaete groups each potentially contain more than 1 species. Cheilostome bryozoans were the most speciose group and together with spirorbid polychaetes were the most abundant group both in terms of numbers of recruits and areal coverage. Taxa recorded on the settlement plates represented $60 \%$ of the full species list recorded on natural substrata at the study sites, 
Table 1. Presence (+) or absence (-) of sessile taxa at the study sites-A: on natural substrata (Bowden 2005b); B: recruiting to plates immersed at monthly intervals from April 2002 to March 2003 (Bowden 2005a); C: on plates immersed continuously for $3 \mathrm{yr}$ (this study). '?': distinct taxa were present but could not be assigned to species

\begin{tabular}{|c|c|c|c|c|c|}
\hline Phylum & Class & $\mathrm{N}$ & $\begin{array}{c}\text { A } \\
\text { Natural } \\
\text { substrata }\end{array}$ & $\begin{array}{c}\text { B } \\
\text { Monthly } \\
\text { immersion }\end{array}$ & $\begin{array}{c}\text { C } \\
\text { Continuous } \\
\text { immersion }\end{array}$ \\
\hline Porifera & Demospongiae & Sponges & $+(7 \mathrm{spp})$ & + & $+(3 \mathrm{spp})$ \\
\hline Cnidaria & Hydrozoa & $\begin{array}{l}\text { Alcyonium antarcticum } \\
\text { Clavularia frankliniana } \\
\text { Primnoella sp. } \\
\text { Urticinopsis antarctica } \\
\text { Hydroids - bush form } \\
\text { Aglaopheniidae } \\
\text { Tubulariidae }\end{array}$ & $\begin{array}{l}+ \\
+ \\
+ \\
+ \\
+ \\
+ \\
+\end{array}$ & $\begin{array}{l}- \\
- \\
+ \\
- \\
- \\
+ \\
-\end{array}$ & $\begin{array}{l}+ \\
- \\
+ \\
- \\
- \\
+ \\
+\end{array}$ \\
\hline Annelida & Polychaeta & $\begin{array}{l}\text { Sabellidae } \\
\text { Serpulidae } \\
\text { Spirorbidae }\end{array}$ & $\begin{array}{l}+ \\
+ \\
+\end{array}$ & $\begin{array}{l}- \\
+ \\
+\end{array}$ & $\begin{array}{l}- \\
+ \\
+\end{array}$ \\
\hline Mollusca & Bivalvia & Adamussium colbecki & + & + & + \\
\hline Bryozoa & $\begin{array}{l}\text { Steno- } \\
\text { laemata }\end{array}$ & $\begin{array}{l}\text { Lichenopora/ } \\
\text { Discoporella spp. } \\
\text { Tubulipora sp.1 } \\
\text { Tubulipora sp.2 } \\
\text { Idmidronea spp. }\end{array}$ & $\begin{array}{l}+ \\
+ \\
+ \\
+\end{array}$ & $\begin{array}{l}? \\
? \\
? \\
?\end{array}$ & $\begin{array}{l}+ \\
+ \\
+ \\
+\end{array}$ \\
\hline & $\begin{array}{l}\text { Gymno- } \\
\text { laemata }\end{array}$ & $\begin{array}{l}\text { Aimulosia antarctica } \\
\text { Arachnopusia inchoata } \\
\text { Beania costata } \\
\text { Beania erecta } \\
\text { Camptoplites bicornis } \\
\text { Celleporella antarctica } \\
\text { Celleporella bougainvillei } \\
\text { Chaperiopsis protecta } \\
\text { Ellisina antarctica } \\
\text { Escaroides tridens } \\
\text { Fenestrulina exigua } \\
\text { Fenestrulina rugula } \\
\text { Figularia discors } \\
\text { Filaguria spatulata } \\
\text { Hippadanella inerma } \\
\text { Lageneschara lyrulata } \\
\text { Micropora brevissima } \\
\text { Micropora notialis } \\
\text { Microporella stenoporta } \\
\text { Smittina rogickae } \\
\text { Toretocheilum absidatum } \\
\text { Valdemunitella lata } \\
\text { Bryozoans - erect indet. }\end{array}$ & $\begin{array}{l}+ \\
+ \\
+ \\
+ \\
+ \\
+ \\
+ \\
+ \\
+ \\
+ \\
+ \\
+ \\
+ \\
+ \\
+ \\
+ \\
+ \\
+ \\
+ \\
+ \\
+ \\
+ \\
+\end{array}$ & $\begin{array}{l}+ \\
+ \\
- \\
+ \\
+ \\
+ \\
+ \\
+ \\
+ \\
- \\
- \\
+ \\
+ \\
- \\
+ \\
+ \\
+ \\
+ \\
- \\
+ \\
- \\
- \\
+\end{array}$ & $\begin{array}{l}+ \\
+ \\
+ \\
+ \\
+ \\
+ \\
- \\
+ \\
+ \\
- \\
- \\
+ \\
+ \\
- \\
+ \\
+ \\
- \\
+ \\
- \\
+ \\
- \\
+ \\
-\end{array}$ \\
\hline $\begin{array}{l}\text { Brachio- } \\
\text { poda }\end{array}$ & Articulata & Liothyrella uva antarctica & + & - & - \\
\hline Chordata & Ascidacea & $\begin{array}{l}\text { Cnemidocarpa verrucosa } \\
\text { Molgula enodis } \\
\text { Styella wandely } \\
\text { Pyura discoveryi } \\
\text { Pyura setosa } \\
\text { Ascidia sp. }\end{array}$ & $\begin{array}{l}+ \\
+ \\
+ \\
+ \\
+ \\
+\end{array}$ & $\begin{array}{l}+ \\
? \\
? \\
? \\
? \\
+\end{array}$ & $\begin{array}{l}+ \\
- \\
- \\
- \\
- \\
+\end{array}$ \\
\hline Algae & Rhodophyta & Coralline encrusting algae & $e+$ & + & + \\
\hline
\end{tabular}

and $85 \%$ of those recruiting to shortterm settlement plates during the second year of immersion (Table 1). However, ascidians, sponges, and anthozoans rarely recruited successfully to plates in the present study, despite frequent settlement of larvae to short-term plates at all sites (Bowden 2005a). Only 4 individuals representing 2 species of ascidians survived on plates after $3 \mathrm{yr}$, and no sponges more than 1 yr old were recorded.

At all locations, at both depths and throughout the immersion period, there were more taxa present on lower surfaces than on upper surfaces of the plates. At $8 \mathrm{~m}$ sites, only coralline algae and spirorbid polychaetes survived on upper surfaces, whereas at $20 \mathrm{~m}$ a total of 12 taxa were recorded on upper surfaces, including serpulid polychaetes, several species of cheilostome bryozoans, 1 hydroid, and 2 specimens of the octocoral Primnoella antarctica. However, these taxa occurred in low numbers as isolated individuals or colonies, and spirorbid polychaetes and coralline algae were again the most widespread and abundant taxa. As total colonisation on all upper surfaces was minimal, the following results refer only to assemblages on the lower surfaces of plates except where specified otherwise.

At $3 \mathrm{yr}$, the mean $( \pm \mathrm{SE})$ number of taxa per plate ranged from $5.0 \pm 0.6$ (Anchorage Island) to $8.0 \pm 1.2$ (Hangar Cove) at $8 \mathrm{~m}$ sites and from $6.0 \pm 0.9$ (Anchorage Island) to $10 \pm 0.4$ (South Cove) at $20 \mathrm{~m}$ sites. Following initial colonisation during the first year of immersion, mean numbers of taxa varied little except at the Anchorage Island $20 \mathrm{~m}$ site where numbers declined from $9.2 \pm 0.9$ after $1 \mathrm{yr}$ to $5.2 \pm 0.9$ after 2 yr and remained low after $3 \mathrm{yr}$. The maximum number of taxa recorded on a single plate undersurface was 14 (Anchorage Island $20 \mathrm{~m}$ site in June 2002). There was little turnover of species underlying these patterns and in most cases the final assemblage after $3 \mathrm{yr}$ consisted largely of the same taxa that had colonised in the first year of immersion 


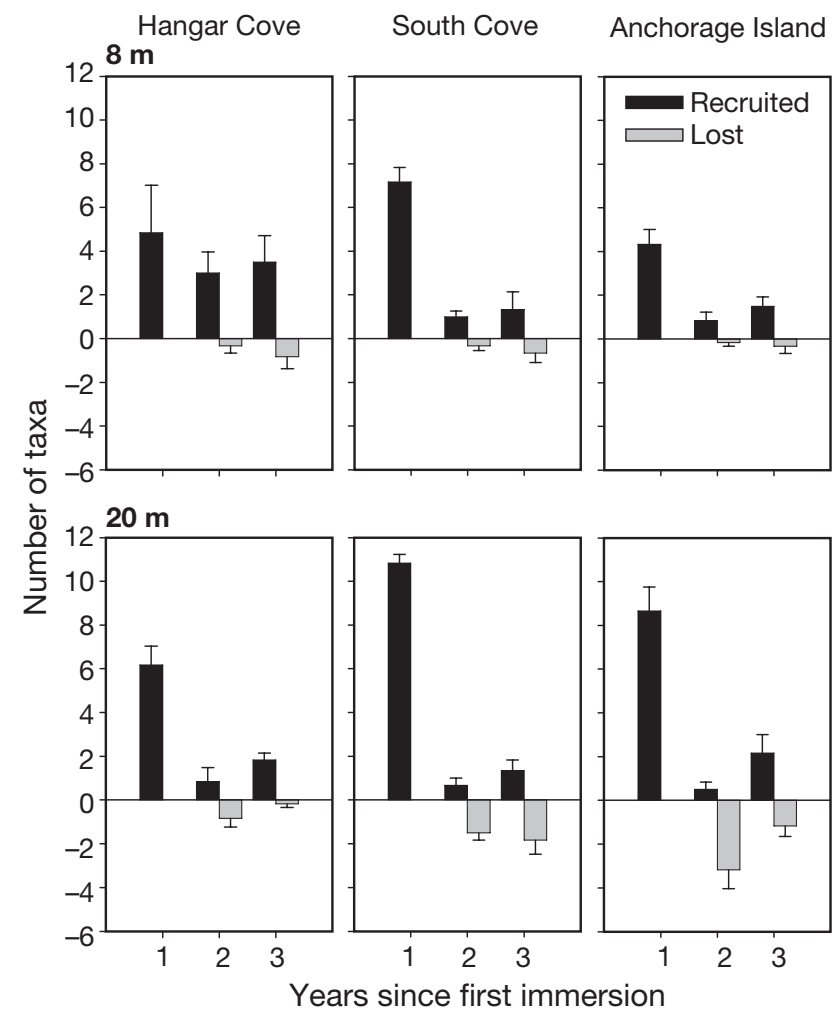

Fig. 2. Taxon turnover on continuously immersed plates over 3 yr (upper and lower surfaces, combined area $300 \mathrm{~cm}^{2}$ ). Positive bars (black) show mean number of new species recorded at end of each year of immersion; negative bars (grey) show mean number of species lost; $\mathrm{n}=6$ plates, error bars are $1 \mathrm{SE}$. Recruitment in Year 1 is significantly greater than in Years 2 and 3 (Kruskal-Wallis tests, $\mathrm{p}<0.05$ ) at all sites except Hangar Cove $8 \mathrm{~m}$, where differences between all years were non-significant

(Fig. 2). Only at the Hangar Cove $8 \mathrm{~m}$ site did similar numbers of new taxa recruit in each year of the study: at all other sites, the majority of taxa recruited during the first year. Indeed, where there was little or no disturbance on the undersurfaces of plates (primarily South Cove), colonies and individuals which were present at the end of the first year generally persisted throughout the study.

Assemblages on panels at $8 \mathrm{~m}$ were typically dominated by spirorbid polychaetes and the cheilostome bryozoans Fenestrulina rugula and Arachnopusia inchoata (Table 2). However, at this depth, spirorbids were substantially less abundant at Hangar Cove than elsewhere. At $20 \mathrm{~m}$ sites, these 3 taxa were again present, but there were differences between locations in the areal coverage and taxonomic composition of assemblages (Table 2). At South Cove, assemblages were dominated by F. rugula, A. inchoata, and the cheilostome bryozoan Chaperiopsis protecta, with spirorbids occupying only ca. $2 \%$ of the total area. At Hangar Cove, plates were similar in taxonomic compo-
Table 2. Assemblages on lower surfaces of acrylic settlement plates at end of 3 yr continuous immersion (February 2001 to February 2004) at 8 and $20 \mathrm{~m}$ depth at the 3 study locations. Taxa within each site are ranked in order of decreasing contribution to overall within-site similarity (SIMPER analysis, $100 \%$ inclusion on 4 th root-transformed data). Abundances are untransformed mean percentage cover, $\mathrm{n}=6$ plates in all cases. Similarity/SD is a relative measure of the consistency of contribution of each taxon to overall within-site similarity; higher values indicate greater consistency

\begin{tabular}{|c|c|c|c|}
\hline \multicolumn{2}{|c|}{ Location } & $\begin{array}{c}\text { Area } \\
\% \text { mean }(\mathrm{SE})\end{array}$ & $\mathrm{Sim} / \mathrm{SD}$ \\
\hline \multicolumn{4}{|c|}{ Hangar Cove } \\
\hline \multirow[t]{9}{*}{$8 \mathrm{~m}$} & Fenestrulina rugula & $35.96(3.39)$ & 7.59 \\
\hline & Spirorbid polychaetes & $1.21(0.24)$ & 5.68 \\
\hline & Arachnopusia inchoata & $3.88(2.66)$ & 5.09 \\
\hline & Beania erecta & $0.18(0.11)$ & 1.34 \\
\hline & Serpulid polychaetes & $0.32(0.14)$ & 1.19 \\
\hline & Micropora notialis & $0.30(0.13)$ & 0.77 \\
\hline & Tubulipora sp. 1 & $0.05(0.04)$ & 0.48 \\
\hline & Camptoplites bicornis & $0.03(0.02)$ & 0.26 \\
\hline & Chaperiopsis protecta & $0.05(0.04)$ & 0.26 \\
\hline \multirow[t]{8}{*}{$20 \mathrm{~m}$} & Spirorbid polychaetes & $1.19(0.47)$ & 6.57 \\
\hline & Serpulid polychaetes & $1.45(0.63)$ & 2.47 \\
\hline & Fenestrulina rugula & $7.04(4.18)$ & 1.24 \\
\hline & Lageneschara lyrulata & $0.28(0.12)$ & 1.16 \\
\hline & Smittina sp. & $0.10(0.05)$ & 0.71 \\
\hline & Tubulipora sp. 1 & $0.01(0.01)$ & 0.77 \\
\hline & Arachnopusia inchoata & $0.02(0.01)$ & 0.26 \\
\hline & Sponges & $0.02(0.01)$ & 0.26 \\
\hline \multicolumn{4}{|c|}{ South Cove } \\
\hline \multirow[t]{10}{*}{$8 \mathrm{~m}$} & Spirorbid polychaetes & $20.81(7.78)$ & 4.75 \\
\hline & Fenestrulina rugula & $45.70(10.06)$ & 1.26 \\
\hline & Ellisina antarctica & $1.49(1.06)$ & 1.29 \\
\hline & Arachnopusia inchoata & $4.15(3.02)$ & 0.43 \\
\hline & Tubulipora sp. 1 & $0.06(0.04)$ & 0.78 \\
\hline & Serpulid polychaetes & $0.22(0.16)$ & 0.48 \\
\hline & Beania erecta & $0.17(0.10)$ & 0.48 \\
\hline & Aimulosia antarctica & $0.06(0.03)$ & 0.47 \\
\hline & Micropora notialis & $0.32(0.27)$ & 0.26 \\
\hline & Alcyonium antarcticum & $0.03(0.03)$ & 0.26 \\
\hline \multirow[t]{12}{*}{$20 \mathrm{~m}$} & Fenestrulina rugula & $54.46(4.51)$ & 9.06 \\
\hline & Chaperiopsis protecta & $6.36(1.83)$ & 7.46 \\
\hline & Spirorbid polychaetes & $1.99(0.42)$ & 6.37 \\
\hline & Arachnopusia inchoata & $4.35(2.47)$ & 1.34 \\
\hline & Serpulid polychaetes & $0.32(0.22)$ & 0.78 \\
\hline & Smittina sp. & $0.20(0.11)$ & 0.78 \\
\hline & Tubulipora sp. 2 & $0.08(0.04)$ & 0.78 \\
\hline & Lichenopora/Discoporella sp. & $0.12(0.08)$ & 0.48 \\
\hline & Tubulipora sp. 1 & $0.11(0.08)$ & 0.48 \\
\hline & Aimulosia antarctica & $0.03(0.01)$ & 0.48 \\
\hline & Ascidia sp. & $1.65(1.63)$ & 0.26 \\
\hline & Tubularia sp. & $0.02(0.01)$ & 0.26 \\
\hline \multicolumn{4}{|c|}{ Anchorage Island } \\
\hline \multirow[t]{7}{*}{$8 \mathrm{~m}$} & Spirorbid polychaetes & $17.00(4.99)$ & 5.23 \\
\hline & Fenestrulina rugula & $9.85(4.64)$ & 3.09 \\
\hline & Ellisina antarctica & $0.07(0.02)$ & 1.29 \\
\hline & Serpulid polychaetes & $0.13(0.10)$ & 0.48 \\
\hline & Arachnopusia inchoata & $0.72(0.56)$ & 0.26 \\
\hline & Lichenopora/Discoporella sp. & $0.06(0.04)$ & 0.26 \\
\hline & Aimulosia antarctica & $0.19(0.17)$ & 0.26 \\
\hline \multirow[t]{8}{*}{$20 \mathrm{~m}$} & Ellisina antarctica & $0.61(0.24)$ & 1.24 \\
\hline & Chaperiopsis protecta & $0.35(0.20)$ & 0.72 \\
\hline & Spirorbid polychaetes & $0.29(0.21)$ & 0.76 \\
\hline & Fenestrulina rugula & $2.59(2.52)$ & 0.47 \\
\hline & Beania erecta & $0.22(0.16)$ & 0.48 \\
\hline & Arachnopusia inchoata & $1.26(0.87)$ & 0.26 \\
\hline & Tubularia sp. & $0.02(0.01)$ & 0.26 \\
\hline & Serpulid polychaetes & $0.11(0.09)$ & 0.26 \\
\hline
\end{tabular}


Table 3. Similarity between assemblages on plate undersurfaces at each of the 6 study sites after $3 \mathrm{yr}$ immersion. Values of the ANOSIM (analysis of similarities) $R$ statistic are given for pairwise comparisons between the 3 study locations at 8 and $20 \mathrm{~m}$ depths: lower values of $R$ indicate greater similarity. Comparisons are based on a matrix of Bray-Curtis similarities between $\mathrm{n}=6$ plates at each depth at each location. No transformation of data was used

\begin{tabular}{|lcc|}
\hline & \multicolumn{2}{c|}{ ANOSIM $R$} \\
& $8 \mathrm{~m}$ & $20 \mathrm{~m}$ \\
\hline Hangar Cove vs. South Cove & 0.344 & 0.706 \\
Hangar Cove vs. Anchorage Island & 0.685 & 0.889 \\
South Cove vs. Anchorage Island & 0.178 & 0.887 \\
\hline
\end{tabular}

sition to those at South Cove, but with a higher abundance of serpulid polychaetes. At Anchorage Island, no taxon survived as more than isolated individuals or colonies during the entire study period. Pairwise multivariate comparisons between assemblages at each of the study sites after $3 \mathrm{yr}$ immersion indicated that similarities across locations were consistently stronger at 8 $\mathrm{m}$ than at $20 \mathrm{~m}$ (For ANOSIM $R$ values see Table 3 ).

\section{Annual changes in total assemblage cover}

On all upper surfaces, throughout the study period, total areal cover was $<10 \%$, including those plates which were not impacted by ice (Fig. 3). Scars where

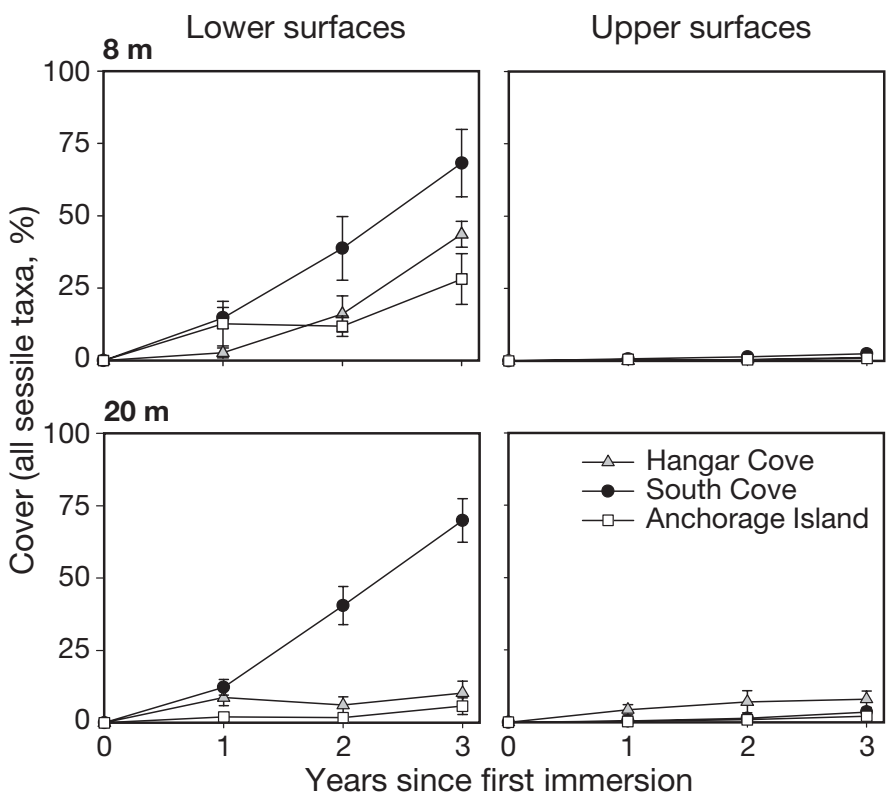

Fig. 3. Total area (\% of substratum) colonised by sessile taxa (mean and SE) on upper and lower surfaces of artificial plates after 1, 2, and 3 yr of continuous immersion (immersion period February 2001 to February 2004). Plates were immersed at 2 depths (8 and $20 \mathrm{~m}$ ) and 3 locations (Hangar Cove, South Cove and Anchorage Island). $\mathrm{n}=6$ plates calcareous polychaetes had been removed, presumably by urchin or limpet grazing, were frequently visible on these surfaces and coralline algae were often the only taxa present by the end of the third year.

On lower surfaces at $8 \mathrm{~m}$, the maximum rate of increase of total assemblage cover (i.e. growth, mortality, and recruitment combined) was similar across all locations, but there were significant differences in mean total coverage at all year-end monitoring points (Fig. 3). At South Cove, assemblages developed at a uniform rate (approximately $25 \%$ of available substratum $\mathrm{yr}^{-1}$ ) to a mean coverage of $68 \pm 11 \%$ (maximum $100 \%$ ) after 3 yr. At Hangar Cove, coverage was minimal at the end of the first year; however, thereafter assemblages developed at the same rate as those in South Cove, and after 3 yr mean coverage was comparable to that on South Cove plates after 2 yr (ca. $40 \%$ ). At Anchorage Island, the mean rate of increase during the first and third years was similar to that at the other locations; however, there was no net increase in the second year, and after 3 yr total coverage was not significantly different from that at Hangar Cove (1-way ANOVA, $F_{2,15}=4.67, \mathrm{p}=0.027$, Tukey post hoc; South Cove $>$ Hangar Cove $=$ Anchorage Island).

On lower surfaces at $20 \mathrm{~m}$, there were major differences between locations in total areal cover (Fig. 3). At South Cove, assemblages followed a pattern similar to that seen at $8 \mathrm{~m}$, with consistent whole-assemblage growth rates of approximately $25 \%$ of available substratum $\mathrm{yr}^{-1}$. At both Hangar Cove and Anchorage Island $20 \mathrm{~m}$ sites, by contrast, total cover was minimal. At Hangar Cove, at the end of the first year of immersion $20 \mathrm{~m}$ plates were similar in areal coverage to those at South Cove. During the winter of the second year of immersion, however, there was a significant decrease in coverage (May-Nov 2002; paired $t$-test, $5 \mathrm{df}, t=$ 2.39, $\mathrm{p}=0.03$, evident in Fig. 4), and total cover remained low throughout the remainder of the study period (maximum cover $26 \%$ after 3 yr). At Anchorage Island, total cover remained very low throughout the study (maximum cover 19\% after 3 yr).

\section{Seasonal changes in total assemblage cover}

Whole assemblage growth was highly seasonal, with no detectable net growth during the winter from June to November and the greatest increases in areal coverage occurring between December and March (Fig. 4). However, the variations in annual growth described above were underlain by pronounced differences in assemblage growth by depth and location at the seasonal level.

To compare overall assemblage development in successive years, curves constructed from mean total coverage measurements at successive monthly inter- 


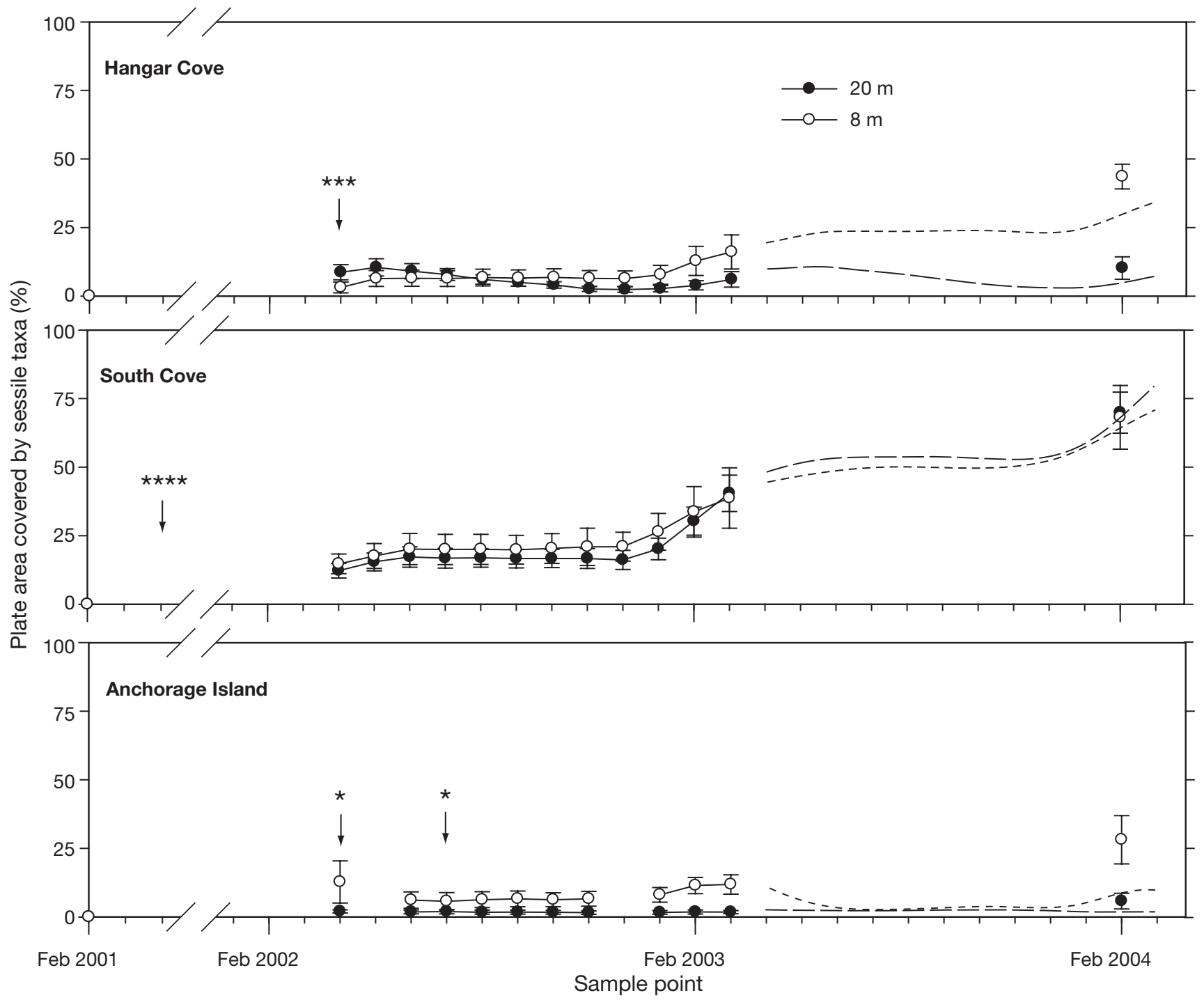

Fig. 4. Total area of substratum (\%) covered by sessile taxa on the lower surfaces of plates (analysed area $150 \mathrm{~cm}^{2}$ ) immersed for $3 \mathrm{yr}$ at each of 3 locations and 2 depths. Values are means, error bars $1 \mathrm{SE}, \mathrm{n}=6$ plates. Assemblage development curves recorded at monthly intervals during the second year of immersion (April 2002 to March 2003) are extrapolated through the third year to the final sampling point in February 2004: long dashes, 20 m; short dashes, $8 \mathrm{~m}$. Arrows: timing of ice impacts (at $8 \mathrm{~m}$ sites only); asterisks: number of plates affected by each impact

vals during the second year of immersion were extrapolated through to the final monitoring point at the end of the third year (Fig. 4, broken lines). As these are direct extrapolations from growth during the second year, the comparisons assume identical disturbances in successive years. In South Cove, at both depths, the extrapolated values for total percentage cover after 3 yr matched closely the values observed at February 2004. At $20 \mathrm{~m}$ sites in Hangar Cove and at Anchorage Island, predicted cover after 3 yr was also close to observed values in February 2004, but realised assemblage growth remained very low $(<15 \%$ cover) for both of these sites. At $8 \mathrm{~m}$ sites in Hangar Cove and at Anchorage Island, by contrast, realised growth after
3 yr was significantly higher than the values predicted from extrapolation of growth through the second year ( $t$-tests, $5 \mathrm{df}$, Hangar Cove $t=9.66, \mathrm{p}<0.001$, Anchorage Island $t=3.22, \mathrm{p}=0.02$ ). Thus, at each $20 \mathrm{~m}$ site, the net growth of assemblages was consistent from year to year but varied in magnitude between locations and was considerably greater in South Cove than elsewhere. At $8 \mathrm{~m}$ sites in Hangar Cove and at Anchorage Island, net growth was greater in the third year than in the second, and during the third year net growth at this depth was comparable at all 3 locations.

These differences in the extent and predictability of assemblage growth correspond with the observed disturbance histories of the sites (Fig. 4, arrows). After 
the first 2 mo of immersion, sites in South Cove were not affected by ice impacts or by significant biotic disturbance, and development proceeded consistently through the remainder of the study. At Hangar Cove and Anchorage Island, $8 \mathrm{~m}$ sites were subject to disturbance from isolated ice impacts in the second year but were undisturbed during the third year and development proceeded at the same rate as that observed in South Cove at this depth (ca. $30 \%$ of plate area from March 2003 to February 2004). At both Hangar Cove and Anchorage Island, however, $20 \mathrm{~m}$ sites were subject to chronic biotic disturbance throughout the second year; this appears to have continued at similar intensity during the third year, preventing assemblage growth.

\section{Growth of individual taxa}

Six faunal taxa were suitable for measurement of seasonal growth: 3 species of cheilostome bryozoans (Arachnopusia inchoata, Chaperiopsis protecta, Fenestrulina rugula), spirorbid polychaetes, serpulid polychaetes, and the solitary ascidian Ascidia sp. It was also possible to measure growth of coralline encrusting algae. However, individual algal recruits were too small for reliable measurement of monthly incremental change during the second year and therefore only annual growth increments were measured.

Growth was strongly seasonal in bryozoans and serpulid polychaetes (Fig. 5), most growth occurring between December and May. For spirorbids, greatest rates of area increase also occurred in this period, but growth apparently continued at low rates throughout the winter (Fig. 5). The solitary ascidian Ascidia sp. grew throughout the year. For the bryozoan species, there was no detectable increase in mean colony area between June and November. However, both the radial growth and specific growth rate metrics (which factor out the effect of initial colony size and thus reduce variance) indicated that Arachnopusia inchoata colonies continued to grow at low rates in all months except September and October (Fig. 6). Radial growth of all 3 bryozoan species was correlated with the concentration of chlorophyll $a$ in the nanoplanktonic fraction of primary production (Fig. 6). The highest mean rate of radial growth recorded for bryozoans was $0.03 \pm$ $0.001 \mathrm{~mm} \mathrm{~d}^{-1}$ for $A$. inchoata in the period from February to March; however, by the specific growth rate measure, Fenestrulina rugula showed the highest mean growth rate $\left(0.022 \pm 0.001 \mathrm{~d}^{-1}\right.$ from January to February). Growth of coralline algae was exponential over the $3 \mathrm{yr}$ of the study (Fig. 7), and maximum algal cover on a single plate after 3 yr was $7.8 \%$ at $8 \mathrm{~m}$ in South Cove.
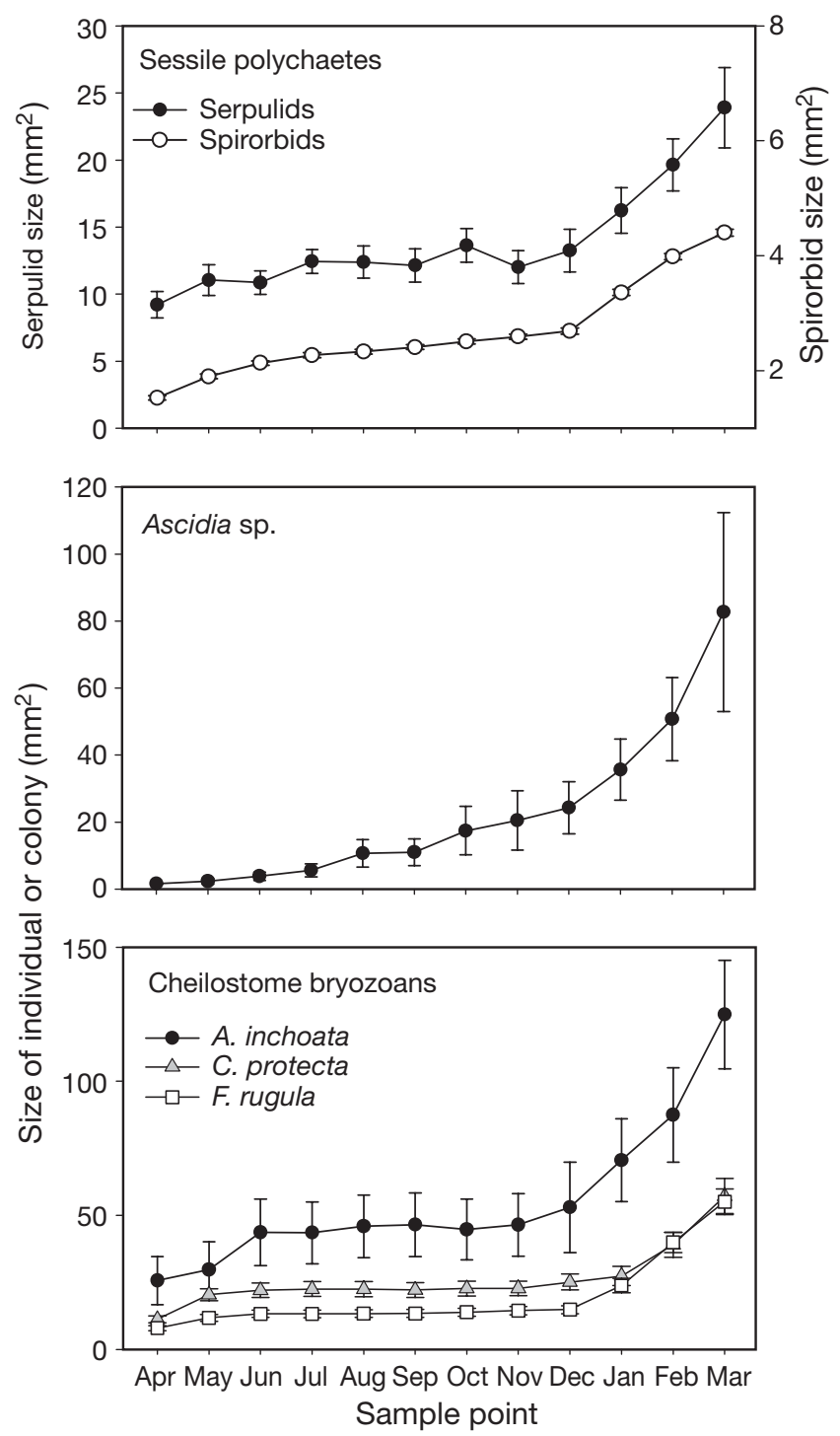

Fig. 5. Sessile polychaetes, Ascidia sp., and cheilostome bryozoans. Growth (increase in area) of undisturbed individuals or colonies from April 2002 to March 2003. Values are means across all locations, error bars 1 SE. Ascidia sp., $\mathrm{n}=3$; serpulids, $\mathrm{n}=11$; spirorbids, $\mathrm{n}=440$; Arachnopusia inchoata, $\mathrm{n}=$ 10; Chaperiopsis protecta, $\mathrm{n}=20$; Fenestrulina rugula, $\mathrm{n}=50$

\section{DISCUSSION}

\section{Comparisons with other studies}

Despite the theoretical advantages of artificial substrata for making direct comparisons between studies, consideration of data from the present study and a range of published studies (Table 4) suggests that such comparisons are not straightforward. Across 3 locations in the present study, total mean cover on undersurfaces after 3 yr ranged from 6 to $70 \%$ and was qualitatively and quantitatively both highly site-specific 

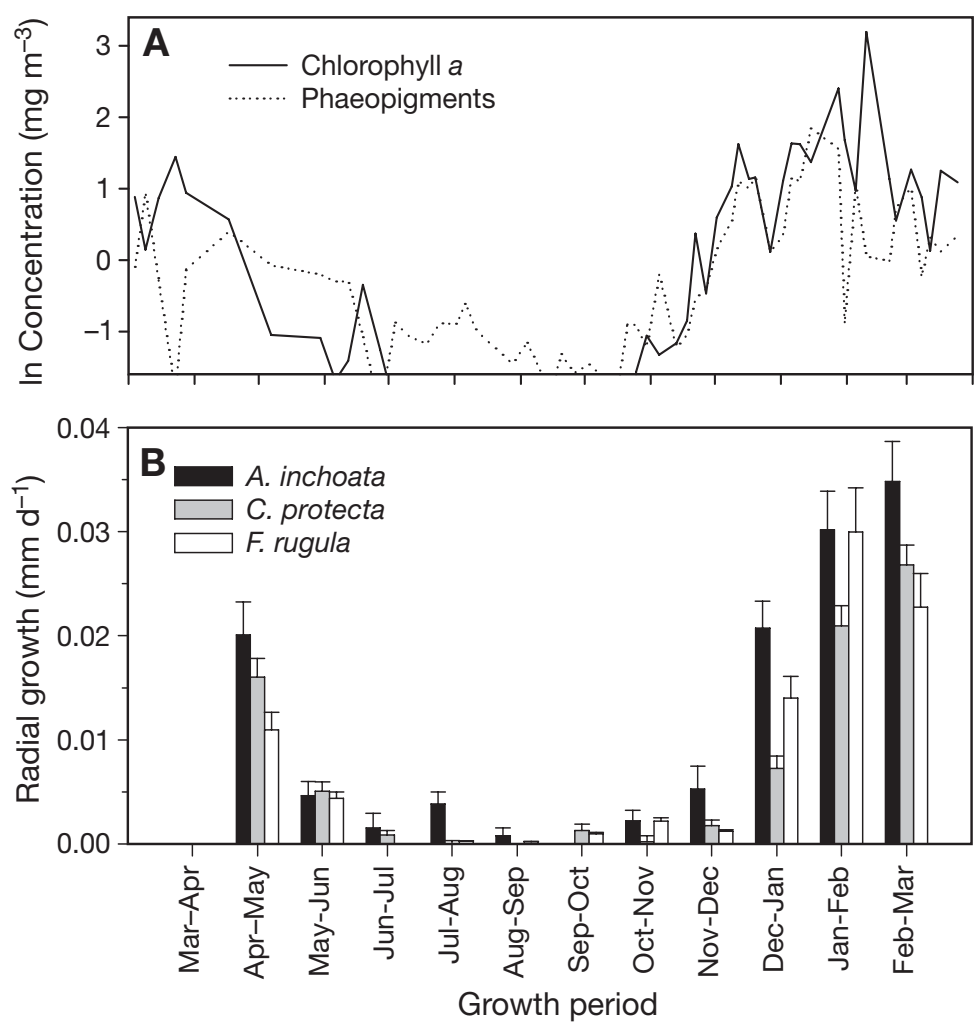

Fig. 6. Arachnopusia inchoata, Chaperiopsis protecta, and Fenestrulina rugula. Seasonal growth rates from April 2002 to March 2003 in relation to nanoplanktonic primary production in the water column. (A) Chlorophyll a (solid line) and phaeopigment (dotted line) concentrations in nanoplankton (2 to $20 \mu \mathrm{m}$ ) at $15 \mathrm{~m}$ depth in Ryder Bay (data from the Rothera Oceanographic and Biological Time Series [RaTS] project: British Antarctic Survey unpubl. data). (B) Radial growth of undisturbed colonies in free space (Means and SE across all locations). Arachnopusia inchoata $\mathrm{n}=10$, Chaperiopsis protecta $\mathrm{n}=20$, Fenestrulina rugula $\mathrm{n}=50$

and depth-dependent, indicating that colonisation can be heavily influenced by local habitat variability at scales of $<5 \mathrm{~km}$. However, many comparable studies report data from only 1 site, and differences in numbers of replicate plates, depths, and the mode and timing of deployment combine to make even general comparisons problematic. Furthermore, spatially dominant taxa in one region may be entirely absent from another, leading to potentially meaningless comparisons.

These caveats notwithstanding, some broad comparisons can be made. There are quantitative and qualitative similarities between the 2 studies conducted at Signy Island (Barnes 1996, Stanwell-Smith \& Barnes 1997) and the present data. Total sessile cover values fall within a common range for each comparable immersion period, and the dominant space-occupying taxa were bryozoans and polychaetes. Many bryozoan species were also common to both locations, but it is notable that the spatial dominance of assemblages by Fenestrulina rugula observed here did not occur at
Signy. The other Antarctic study (Rauschert 1991), however, reached a very different endpoint after $3 \mathrm{yr}$, with substrata being dominated almost entirely by solitary ascidians. This is also the only Antarctic study (those available are cited above) in which plates were suspended above the seabed, and it is therefore likely that they were largely free from grazing and disturbance by benthic macrofauna.

Data from temperate studies indicate a considerably more rapid increase in sessile cover than in the Antarctic, with evidence that assemblages on both suspended and benthic substrata can reach 75 to $100 \%$ cover within 1 yr compared with a maximum of $15 \%$ recorded in the Antarctic after 1 yr. However, 2 of these studies (Osman 1977, Greene et al. 1983) used suspended plates, and ascidians were again significant occupiers of space; furthermore, both Osman (1977) and Greene et al. (1983) noted that there was no evidence of predation during their studies. It is also interesting that a large contribution to overall cover in these studies was from barnacles, a taxon which is absent from Antarctic encrusting assemblages. Perhaps more interesting is the variability of areal cover within studies. For instance, both Osman (1977) and Greene et al. (1983) noted significant declines in areal coverage after initial rapid colonisation, and Todd (1998) observed mean coverage which varied depending on the season of initial immersion. Many of these fluctuations were associated with rapid colonisation,

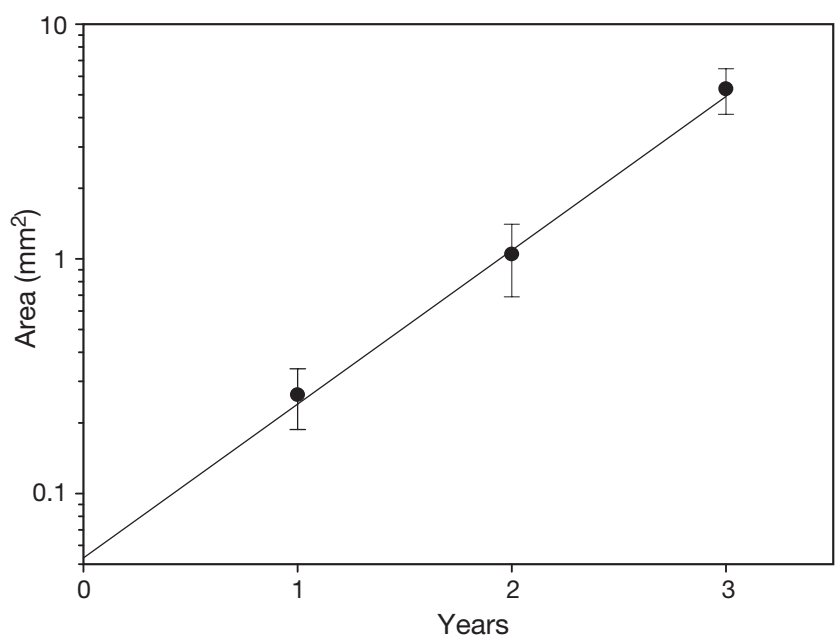

Fig. 7. Coralline algae. Growth of undamaged recruits over $3 \mathrm{yr}$ on settlement plates at $8 \mathrm{~m}$ in South Cove. Mean and SE. Growth: $y=0.0422 \mathrm{e}^{1.613 x}, \mathrm{r}^{2}=0.966$ 
growth and subsequent decline of a single species within $1 \mathrm{yr}$, and the assemblage dynamics thus differ fundamentally from the persistent species composition and slow growth seen in the present study.

Tropical assemblages also may develop more rapidly than those in the Antarctic but there are few comparable data. In the longest and most detailed of the tropical studies (Winston \& Jackson 1984), the dominant taxa on undersurfaces during early colonisation (up to ca. $1.5 \mathrm{yr}$ ) were coralline algae. However, the spongeand bryozoan-dominated assemblage which developed later increased at rates similar to those observed for these taxa in the present study (Table 4, Fig. 8). In terms of methodology, replication, mode of deployment, and duration, the data of Winston \& Jackson (1984) are the most directly comparable with the present study, and none of the obvious confounding factors associated with such comparisons appear to apply. Given the high growth rates reported for some tropical bryozoans (McKinney \& Jackson 1989), it seems unlikely that the similarity in rates of increase is a reflection of similarity in unimpeded growth rates. Predation and interspecific competition for both space (Winston \& Jackson 1984) and planktonic food (Buss \& Jackson 1981) can be significant in cryptic coral reef assemblages, and Winston \& Jackson's (1984) data may reflect limitation by these processes rather than slow growth rates per se. It would, however, be of interest to compare the total annual availability of planktonic food in persistently oligotrophic tropical waters with that in seasonally highly eutrophic Antarctic waters.

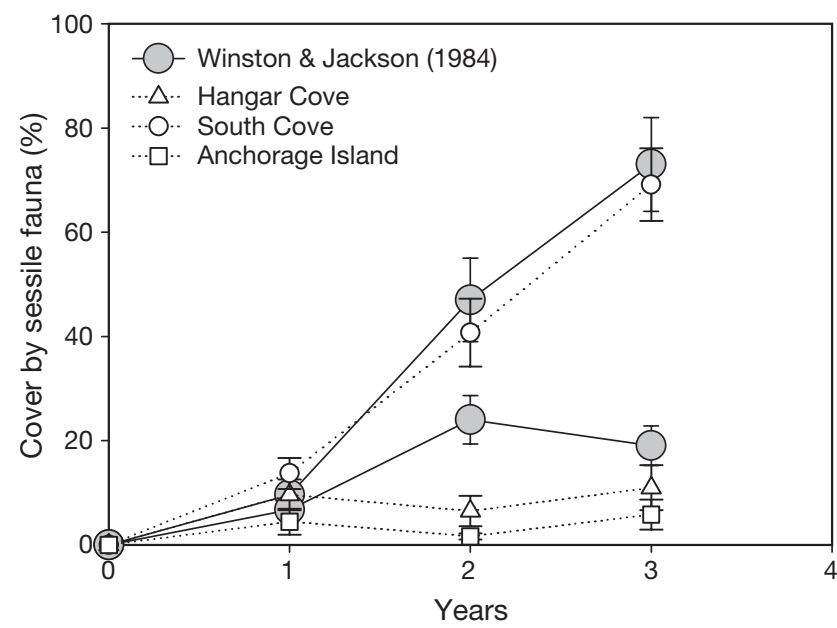

Fig. 8. Comparison of total \% cover by sessile epifauna on the undersurfaces of artificial substrata at 3 sites in the present study (Hangar Cove, South Cove, Anchorage Island) and 2 sites on a Jamaican coral reef studied by Winston \& Jackson (1984). Note that coralline algae have been excluded from the Winston \& Jackson data. Present study data are from $20 \mathrm{~m}$, plate area $150 \mathrm{~cm}^{2}, \mathrm{n}=6$. Winston \& Jackson data are from $13 \mathrm{~m}$, plate area $225 \mathrm{~cm}^{2}, \mathrm{n}=6$
Thus, by the coarse measure of total percentage cover, Antarctic sessile assemblages take 2.5 to 3 times longer to reach a mean coverage of $>50 \%$ than do similar assemblages in temperate latitudes. The realised growth rates of comparable sessile assemblages in the tropics, however, may be similar to those in polar latitudes. The hypothesis of slower colonisation in the Antarctic is, therefore, only partially supported by the rates of assemblage development recorded in the present study.

\section{Growth}

Growth was seasonal and coincident with the period of planktonic primary production, thus supporting the second hypothesis (see 'Introduction'). Evidence of continuing growth throughout the year in Ascidia sp., spirorbid polychaetes, and Arachnopusia inchoata (Figs. 5 \& 6), however, implies that the ability to exploit limited winter resources, whether from nanoplankton production, resuspension events, or other sources, may be an adaptive advantage. Two of these taxa were conspicuously successful: spirorbids recruited throughout the year at all of the study sites (Bowden 2005a) and were the most abundant and ubiquitous single taxon in the study, while $A$. inchoata exhibited the highest and most sustained growth rates of all the bryozoans and attained the largest mean colony size. Although only 3 individuals of Ascidia sp. survived, this species exhibited the most rapid rates of increase of any taxon. Solitary ascidians are highly vulnerable to predation in the period immediately following settlement (Osman \& Whitlatch 1995, 2004), and survivorship of ascidians on plates in the present study was low. It is likely, therefore, that the potential to reach a size refuge from predation through year-round growth is important for the persistence of this taxon.

Of the individual taxa for which growth was measured, the bryozoan species, because of their simplicity of growth form, offer the best prospect for comparisons of growth rate with other latitudes. The highest monthly mean specific growth rates recorded in the present study did not differ significantly between the 3 Antarctic bryozoan species. However, all rates were significantly lower than those reported by Hermansen et al. (2001) for a range of temperate bryozoan species under varying conditions; median values for the Antarctic species were approximately 5 to 7 times lower than for the temperate species (Fig. 9). No suitable data are available to allow calculation of specific growth rates for tropical species, but Winston \& Jackson (1984) note that cheilostome growth rates in their study were 'generally slow' compared to those reported for temperate species. Perhaps more intuitively 


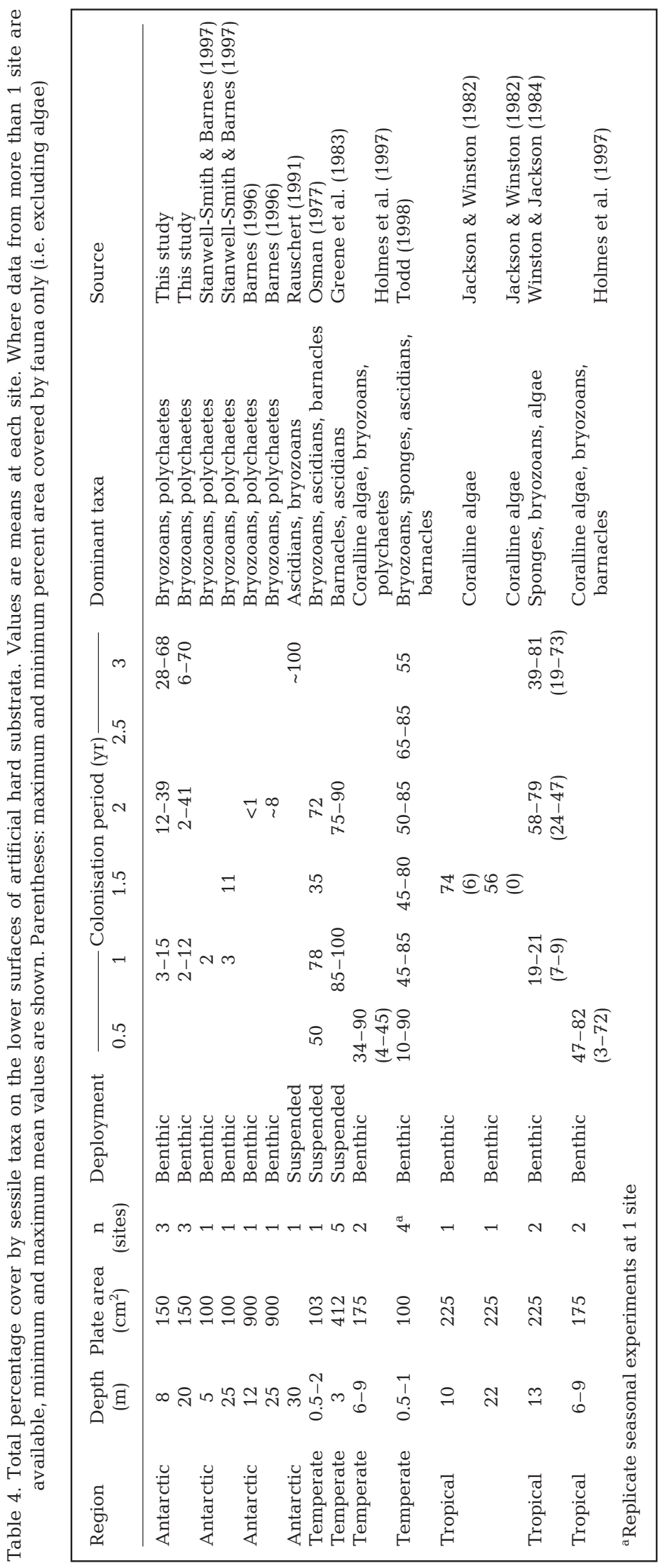

useful for the comparison of growth rates is the measurement of radial growth, but few studies provide data from which this rate can be calculated reliably. Values that are available range from $1 \mathrm{~mm} \mathrm{~d}^{-1}$ (Conopeum seurati, O'Dea \& Okamura 1999) to $0.3 \mathrm{~mm} \mathrm{~d}^{-1}$ (Valdemunitella valdemunita, Vail \& Wass 1981), and these contrast with the highest rate recorded in the present study of $0.03 \mathrm{~mm} \mathrm{~d}^{-1}$ (Arachnopusia inchoata, February to March 2003). These values suggest that even during the period of peak summer growth when food supply is unlikely to be limiting, maximum growth rates of bryozoans in the Antarctic may be at least 5 to 10 times slower than those in temperate latitudes. These comparisons lend support to the hypothesis that the low annual growth rates generally observed in Antarctic marine fauna are related to the physiological effects of low temperature per se (Hoegh-Guldberg \& Pearse 1995, Fraser et al. 2002a) rather than to resource limitation caused by a reduced period of primary production (Clarke 1988, 1991, Clarke et al. 2004).

\section{Disturbance}

In combination with the abundance and taxonomic diversity of monthly recruitment recorded at all sites during the study by Bowden (2005a), the low levels of colonisation on exposed upper surfaces and the equilibrium in species number over 3 yr observed in the present study suggest that sessile assemblages in the area are strongly affected by post-settlement processes. However, although the depth gradient of ice-mediated disturbance is clearly important, as evidenced here by the relative frequency of impacts at shallow and deep sites, it is not sufficient alone to explain observed patterns of survivorship in the present study: few plates were affected by ice, and biological disturbances from a range of taxa generally exerted a stronger influence on patterns of colonisation.

The most consistent ecological pattern in the present study was the paucity of colonisation on plate upper surfaces, and this appears to be primarily a consequence of grazing. Several generalist molluscan grazers (e.g. Nacella concinna, Iothia coppingeri, and Margarella antarctica) and the urchin Sterechinus neumayeri are abundant in the study area (Bowden 2005b). Grazing and predation by molluscs has 


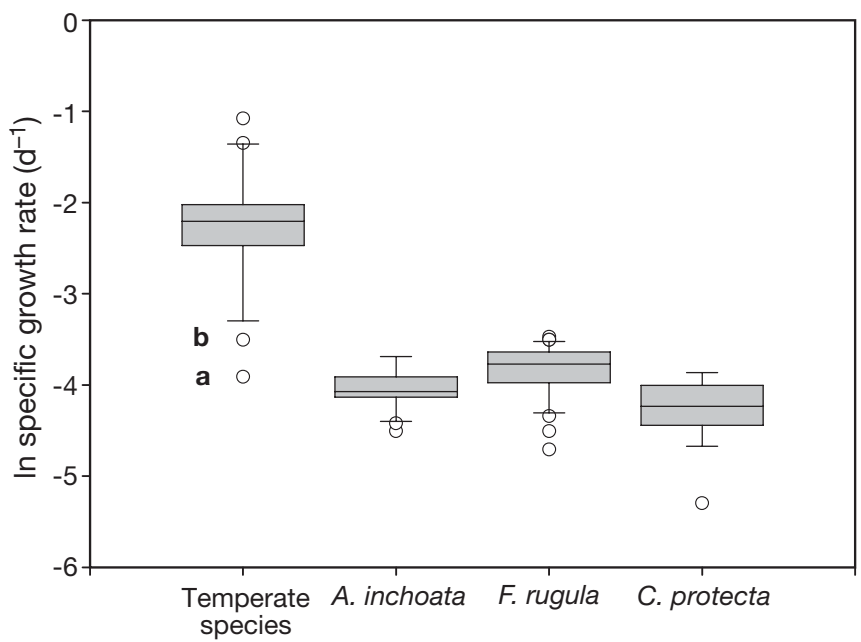

Fig. 9. Specific growth rates of 3 Antarctic bryozoan species in the present study compared with pooled data for 6 temperate latitude encrusting bryozoan species. Temperate species data are taken directly from Table 7 in Hermansen et al. (2001) and include both field and laboratory studies but exclude erect species. Data from the present study are from unrestricted colonies during months of maximum radial growth for each species: Arachnopusia inchoata and Chaperiopsis protecta, April-May 2002 and February-March 2003; Fenestrulina rugula, January-February 2003. One-way ANOVA on lntransformed data, $F_{3,92}=47.9, \mathrm{p}<0.0001$, Tukey-Kramer post hoc, Temperate species $>A$. inchoata $=F$. rugula $=C$. protecta. (a: Celleporella hyalina; b: Electra pilosa - rates from lowest algal concentrations in laboratory growth studies)

been shown to cause significant mortality of early recruits of sessile taxa immediately after settlement in temperate latitudes (Turner \& Todd 1991, Osman \& Whitlatch 1995). Grazing by $S$. neumayeri, however, can completely remove bryozoans, spirorbids, and serpulids which have been established for 1 yr (Bowden 2005c) and can also exert a strongly negative effect on early recruitment (Bowden 2005a). Thus, at the consistently high population densities found in the study area, grazers, particularly the urchin $S$. neumayeri, appear to be a major factor controlling the rate of assemblage development on exposed hard substrata.

The pronounced differences between sessile assemblages on plate undersurfaces across locations at $20 \mathrm{~m}$ were also evidently the result of biological disturbances. Undersurfaces were assumed to be protected from most grazing activity by the restricted gap between the settlement plate and base panel (10 $\mathrm{mm})$ but a range of generalist grazers (as above), predators (e.g. opisthobranch molluscs, pycnogonids, nemerteans, isopods, and errant polychaetes) and crevice-occupying deposit and suspension feeding taxa (terebellid polychaetes and holothurians) affected assemblage development on these surfaces. Although upper surfaces were grazed intensively across all study sites at this depth, it is significant that undersurfaces at $20 \mathrm{~m}$ were subject to different types and intensities of biotic disturbance at each location. The winter decline in colonised area observed on plates at this depth in Hangar Cove (Fig. 4) was caused by the grazing activities of small urchins (<10 mm diameter), which were able to enter the space between plate and base panel. The very low levels of survivorship observed throughout the study at Anchorage Island, by contrast, were evidently the result of disturbance by terebellid polychaetes and nemertean worms. Terebellids, in particular, constructed sediment and gravel tubes in the space between the settlement plate and the base panel. Adult terebellids were surprisingly mobile and it was not uncommon for large adults (up to $150 \mathrm{~mm}$ length) to occupy settlement units and construct substantial tubes during the time between monitoring points (ca. $30 \mathrm{~d}$ ). Once established, however, the majority of these terebellids persisted throughout the study, their tubes occupying large areas of plate surfaces and thus reducing the free space available to potential recruits of other taxa. At South Cove, although individual bryozoan colonies were occasionally removed by selective predation, possibly by opisthobranch molluscs (Barnes \& Bullough 1996), disturbance was minimal.

Disturbances from ice impact and from the activities of macrofauna operated on different temporal and spatial scales and exerted very different effects on the development of sessile assemblages. Ice impacts affected only the sites at $8 \mathrm{~m}$, and each impact was an isolated event which did not recur during the course of the study. Significantly, although these impacts were catastrophic for the assemblages affected, not all plates within a site were hit and, across all $8 \mathrm{~m}$ sites, $50 \%$ of plates remained unaffected by ice after $3 \mathrm{yr}$. This pattern of disturbance resulted in significant variability in colonisation stage within individual sites but strong similarities between sites across locations. In contrast to this, biotic disturbances evidently continued at the same intensity from one year to the next and affected all plates within the sites where they occurred. For assemblages on lower surfaces, this resulted in a pattern of high similarity between assemblages on plates within each site but significant differences between sites across locations (Table 3).

Thus, there are apparently scale-dependent differences in the effects of disturbance which vary according to the causal mechanism. Ice disturbance is acute, localised, and stochastic, permitting the existence of both physical and temporal refugia for sessile taxa: the former through the variability of seabed topography and the latter through the unpredictability of repeat impacts. This results in spatially heterogeneous assemblages at small scales (m) but homogeneity when viewed at larger scales $(\mathrm{km})$. Biological disturbance, by 
contrast, is chronic and targeted (whether at prey species or the habitat itself) and results in homogeneity at small scales and heterogeneity at larger scales. The control of recruitment success by biological factors has been shown to maintain local assemblage structure in temperate epifaunal habitats over several years (Osman \& Whitlatch 2004), and the consistent differences between the $20 \mathrm{~m}$ sites in the present study over 3 yr appear to be the result of similar processes. What remains unclear here, however, is why there should be so little biotic disturbance on the undersurfaces of plates at the $20 \mathrm{~m}$ site in South Cove when plates at this depth in the other 2 locations were so heavily affected.

\section{Succession and the timing of disturbance}

The implications of strongly seasonal growth in the Antarctic extend to considerations of the influence of timing of disturbance on the kind of assemblage that develops. Substrata in temperate studies can develop very different assemblages, depending on the timing of first immersion (Sutherland 1974, Todd 1998), indicating that the timing of disturbance, and hence the availability of free space, can be an important factor determining the taxonomic composition of assemblages. This effect is primarily caused by the preemption of space by initial recruits which settle in high densities and grow rapidly (e.g. Ascidia sp. in Sutherland 1974, Ascidiella scabra in Todd 1998); the identity of these initial colonists depends on when the disturbance occurs in relation to species-specific settlement periods (Sutherland 1974). In the Antarctic, however, restricted and strongly seasonal growth may negate the potential for such 'lottery' effects (Greene \& Schoener 1982) to be generated by variations in the timing of disturbance.

The pre-emption of space requires that growth should occur before other competing taxa recruit to the substratum. However, if most growth takes place within a single short season, none of the recruits which have settled between the end of one growing season and the beginning of the next will have grown significantly. Therefore, all recruits will be at essentially the same size at the start of summer, regardless of when they settled. In the present study, first immersion was in February at the end of the summer period of maximum growth. Therefore, growth was negligible for all taxa during the subsequent 8 to 9 mo leading up to the beginning of the next summer. Thus, because the competition for space occupation effectively only begins once all competitors are assembled, there is little potential within a single year for any taxon to gain a growth advantage. As competitive overgrowth inter- actions within high-latitude sessile assemblages are more deterministic than elsewhere (Barnes 2002), it also seems probable that the subsequent development of the assemblage will follow a largely predictable course.

In the absence of disturbance, therefore, the combination of slow, temporally restricted growth with consistent annual recruitment of larvae may result in successional processes during early colonisation being largely deterministic, with the occupation of free space being achieved primarily by high density of recruitment rather than by competitive interaction or differential growth rates. As free substratum is required for the settlement of most of the sessile taxa involved, the rapid occupation of space through abundant recruitment, even by competitively inferior species, can have a significant inhibitory effect on the recruitment of competitors. The stability over $3 \mathrm{yr}$ of assemblages dominated by Fenestrulina rugula in South Cove may be an expression of such inhibition. F. rugula has limited competitive overgrowth ability (Barnes \& Rothery 1996) but produces large numbers of larvae which recruit within a relatively short period in early summer (Bowden 2005a), and exhibits maximum growth rates immediately after settlement (Fig. 6). The combination of high density of settlement and strong initial growth results in the growing margins of individual colonies meeting conspecifics within a relatively short time (1 to $2 \mathrm{yr}$ ) and thus pre-empting settlement by other taxa. Although competitive overgrowth interactions became significant in our study after $3 \mathrm{yr}$, initial rapid space occupation by $F$. rugula significantly reduced the potential for the competitive dominants Arachnopusia inchoata and Chaperiopsis protecta to recruit during this time. No instances of intraspecific overgrowth were observed in F. rugula and, as most cheilostome bryozoans have short-dispersal lecithotropic larvae (Jackson 1986, McKinney \& Jackson 1989, Todd 1998), it is likely that most colonies on a single plate are closely related to each other. Thus, by investing in recruitment, a single lineage can potentially occupy substratum more rapidly than would be possible by growth alone in an environment where growth rates are low. The conspicuous spatial domination by $F$. rugula in these assemblages suggests that this is a successful strategy.

Acknowledgements. We thank all in the marine team at Rothera from 2000 to 2003, particularly P. Horne, R. Piper, W. Gilchrist and J. Burleigh for diving and boating support. Dr. A. Fleming and Dr. P. Cooper at the British Antarctic Survey (BAS) helped to develop image analysis procedures, and Prof. C. Todd at the University of St. Andrews provided constructive criticism on an earlier version of the manuscript. This study formed part of the Life At The Edge: Stresses and Thresholds (LATEST) research programme of the BAS. 


\section{LITERATURE CITED}

Arntz WE, Brey T, Gallardo VA (1994) Antarctic zoobenthos. Oceanogr Mar Biol 32:241-304

Barnes DKA (1995) Seasonal and annual growth in erect species of Antarctic bryozoans. J Exp Mar Biol Ecol 188:181-198

Barnes DKA (1996) Low levels of colonisation in Antarctica: the role of bryozoans in early community development. In: Gordon DP, Smith AM, Grant-Mackie JA (eds) Bryozoans in space and time. Proc 10th Int Bryozoology Conf. National Institute of Water \& Atmospheric Research, Wellington, p 19-28

Barnes DKA (1999) The influence of ice on polar nearshore benthos. J Mar Biol Assoc UK 79:401-407

Barnes DKA (2002) Polarization of competition increases with latitude. Proc R Soc Lond Ser B Biol Sci 269:2061-2069

Barnes DKA, Arnold R (2001) A growth cline in encrusting benthos along a latitudinal gradient within Antarctic waters. Mar Ecol Prog Ser 210:85-91

Barnes DKA, Bullough LW (1996) Some observations on the diet and distribution of nudibranchs at Signy Island, Antarctica. J Molluscan Stud 62:281-287

Barnes DKA, Clarke A (1995) Seasonality of feeding activity in Antarctic suspension feeders. Polar Biol 15:335-340

Barnes DKA, Rothery P (1996) Competition in encrusting Antarctic bryozoan assemblages: outcomes, influences and implications. J Exp Mar Biol Ecol 196:267-284

Bernhardt SP, Griffing LR (2001) An evaluation of image analysis at benthic sites based on color segmentation. Bull Mar Sci 69:639-653

Bowden DA (2005a) Seasonality of recruitment in Antarctic sessile marine benthos. Mar Ecol Prog Ser 297:101-118

Bowden DA (2005b) Quantitative characterisation of shallow marine benthic assemblages at Ryder Bay, Adelaide Island, Antarctica. Mar Biol 146:1235-1249

Bowden DA (2005c) Benthic assemblage development and larval ecology of sessile marine invertebrates at Adelaide Island, Antarctica. PhD thesis, Open University, Milton Keynes

Brockington S, Clarke A, Chapman ALG (2001) Seasonality of feeding and nutritional status during the austral winter in the Antarctic sea urchin Sterechinus neumayeri. Mar Biol 139:127-138

Brown KM, Fraser KP, Barnes DK, Peck LS (2004) Links between the structure of an Antarctic shallow-water community and ice-scour frequency. Oecologia 141:121-129

Buss LW, Jackson JBC (1981) Planktonic food availability and suspension-feeder abundance-evidence of in situ depletion. J Exp Mar Biol Ecol 49:151-161

Clarke A (1988) Seasonality in the Antarctic marine environment. Comp Biochem Physiol B Comp Biochem Mol Biol 90:461-473

Clarke A (1991) What is cold adaptation and how should we measure it? Am Zool 31:81-92

Clarke A, Leakey RJG (1996) The seasonal cycle of phytoplankton, macronutrients, and the microbial community in a nearshore Antarctic marine ecosystem. Limnol Oceanogr 41:1281-1294

Clarke A, Prothero-Thomas E, Beaumont JC, Chapman AL, Brey T (2004) Growth in the limpet Nacella concinna from contrasting sites in Antarctica. Polar Biol 28:62-71

Clarke KR, Warwick RM (2001) Change in marine communities: an approach to statistical analysis. PRIMER-E, Plymouth

Dayton PK (1989) Interdecadal variation in an Antarctic sponge and its predators from oceanographic climate shifts. Science 245:1484-1486
Dayton PK (1990) Polar benthos. In: Smith WO (ed) Polar oceanography. Academic Press, London, p 631-685

Dayton PK, Robilliard GA, Paine RT, Dayton LB (1974) Biological accommodation in the benthic community at McMurdo Sound, Antarctica. Ecol Monogr 44:105-128

Fraser KPP, Clarke A, Peck LS (2002a) Low-temperature protein metabolism: seasonal changes in protein synthesis and RNA dynamics in the Antarctic limpet Nacella concinna Strebel 1908. J Exp Biol 205:3077-3086

Fraser KPP, Clarke A, Peck LS (2002b) Feast and famine in Antarctica: seasonal physiology in the limpet Nacella concinna. Mar Ecol Prog Ser 242:169-177

Greene CH, Schoener A (1982) Succession on marine hard substrata: a fixed lottery. Oecologia 55:289-297

Greene CH, Schoener A, Corets E (1983) Succession on marine hard substrata: the adaptive significance of solitary and colonial strategies in temperate fouling communities. Mar Ecol Prog Ser 13:121-129

Gutt J (2001) On the direct impact of ice on marine benthic communities, a review. Polar Biol 24:553-564

Gutt J, Starmans A (2001) Quantification of iceberg impact and benthic recolonisation patterns in the Weddell Sea (Antarctica). Polar Biol 24:615-619

Hermansen P, Larsen PS, Riisgard HU (2001) Colony growth rate of encrusting marine bryozoans (Electra pilosa and Celleporella hyalina). J Exp Mar Biol Ecol 263:1-23

Hoegh-Guldberg O, Pearse JS (1995) Temperature, food availability, and the development of marine invertebrate larvae. Am Zool 35:415-425

Holmes NJ, Harriott VJ, Banks SA (1997) Latitudinal variation in patterns of colonisation of cryptic calcareous marine organisms. Mar Ecol Prog Ser 155:103-113

Jackson JBC (1986) Modes of dispersal of clonal benthic invertebrates-consequences for species distributions and genetic structure of local populations. Bull Mar Sci 39:588-606

Jackson JBC, Winston JE (1982) Ecology of cryptic coral-reef communities. 1. Distribution and abundance of major groups of encrusting organisms. J Exp Mar Biol Ecol 57: 135-147

McKinney FK, Jackson JBC (1989) Bryozoan Evolution. University of Chicago Press, Chicago, IL

O'Dea A, Okamura B (1999) Influence of seasonal variation in temperature, salinity and food availability on module size and colony growth of the estuarine bryozoan Conopeum seurati. Mar Biol 135:581-588

Osman RW (1977) The establishment and development of a marine epifaunal community. Ecol Monogr 47:37-63

Osman RW, Whitlatch RB (1995) Predation on early ontogenic life stages and its effect on recruitment into a marine epifaunal community. Mar Ecol Prog Ser 117:111-126

Osman RW, Whitlatch RB (2004) The control of the development of a marine benthic community by predation on recruits. J Exp Mar Biol Ecol 311:117-145

Pearse JS, McClintock JB, Bosch I (1991) Reproduction of Antarctic benthic marine invertebrates - tempos, modes, and timings. Am Zool 31:65-80

Peck LS, Brockington S, Brey TA (1997) Growth and metabolism in the Antarctic brachiopod Liothyrella uva. Philos Trans R Soc Lond Ser B Biol Sci 352:851-858

Peck LS, Colman JG, Murray AWA (2000) Growth and tissue mass cycles in the infaunal bivalve Yoldia eightsi at Signy Island, Antarctica. Polar Biol 23:420-428

Rauschert M (1991) Ergebnisse der faunistischen Arbeiten im Benthal von King George Island (Südshetlandinseln, Antarktis). Ber Polarforsch Meeresforsch 76 
Schoener A, Long ER, DePalma JR (1978) Geographic variation in artificial island colonization curves. Ecology 59: 367-382

Stanwell-Smith D, Barnes DKA (1997) Benthic community development in Antarctica: recruitment and growth on settlement panels at Signy Island. J Exp Mar Biol Ecol 212:61-79

Sutherland JP (1974) Multiple stable points in natural communities. Am Nat 108:859-873

Teixido N, Garrabou J, Arntz WE (2002) Spatial pattern quantification of Antarctic benthic communities using landscape indices. Mar Ecol Prog Ser 242:1-14

Todd CD (1998) Larval supply and recruitment of benthic invertebrates: Do larvae always disperse as much as we believe? Hydrobiologia 376:1-21

Editorial responsibility: Howard I. Browman (Associate Editor-in-Chief), Storebø, Norway
Turner SJ, Todd CD (1991) The effects of Gibbula cineraria (L), Nucella lapillus (L) and Asterias rubens (L) on developing epifaunal assemblages. J Exp Mar Biol Ecol 154: 191-213

Vail LL, Wass RE (1981) Experimental studies on the settlement and growth of bryozoa in the natural environment. Aust J Mar Freshw Res 32:639-656

Winston JE, Jackson JBC (1984) Ecology of cryptic coral reef communities 4. Community development and life histories of encrusting cheilostome Bryozoa. J Exp Mar Biol Ecol $76: 1-21$

Witman JD, Etter RJ, Smith F (2004) The relationship between regional and local species diversity in marine benthic communities: a global perspective. Proc Natl Acad Sci USA 101:15664-15669

Submitted: November 14, 2005; Accepted: February 20, 2006 Proofs received from author(s): June 8, 2006 